\title{
Health Condition and Test Availability as Predictors of Adults' Mental Health during the COVID-19 Pandemic
}

\author{
Huiyang Dai \\ Doctoral Student, Tsinghua University, Beijing, China \\ Stephen X. Zhang* \\ Associate Professor, University of Adelaide, Adelaide, Australia
}

Kim Hoe Looi

Assistant Professor, Xiamen University Malaysia, Malaysia

Rui Su

Bachelor Student, Xiamen University Malaysia, Malaysia

Jizhen Li

Associate Professor, Tsinghua University, Beijing, China

*Corresponding author: Stephen X. Zhang, stephen.X.zhang@gmail.com; Phone: +61 8831

39310; Address: 9-28 Nexus10 Tower, 10 Pulteney St, Adelaide SA 5000, Australia 


\section{Health Condition and Test Availability as Predictors of Adults' Mental Health during the COVID-19 Pandemic}

\section{ABSTRACT \\ Background:}

Research identifying adults' mental health during the COVID-19 pandemic relies solely on demographic predictors without examining adults' health status during the COVID-19 pandemic as a potential predictor.

\section{Methods:}

An online survey of 669 adults in Malaysia was conducted during May 2-8, 2020, six weeks after a Movement Control Order (MCO) was issued.

\section{Findings:}

Adults' health condition had curvilinear relationships (horizontally reversed J-shaped) with insomnia, anxiety, depression and distress. Reported test availability for COVID-19 (from "strongly disagree" to "strongly agree") also had curvilinear relationships (horizontally reversed J-shaped) with anxiety and depression. Younger adults reported worse mental health, but people from various religions and ethnic groups did not differ significantly in reported mental health.

\section{Interpretation:}

Adults with worse health conditions had more mental health problems, especially adults at the lower end of the health spectrum. Test availability negatively predicted anxiety and depression, especially for adults experiencing poor COVID-19 test availability. The significant predictions of health condition and COVID-19 test 
medRxiv preprint doi: https://doi.org/10.1101/2020.06.21.20137000; this version posted June 23, 2020. The copyright holder for this preprint (which was not certified by peer review) is the author/funder, who has granted medRxiv a license to display the preprint in perpetuity.

It is made available under a CC-BY-NC-ND 4.0 International license .

availability suggest a new direction for the literature to identify psychiatric risk factors directly from health related variables during a pandemic.

\section{Funding:}

Tsinghua University-INDITEX Sustainable Development Fund (Project No. TISD201904).

Keywords: psychiatric screening; health condition; COVID-19 test availability; risk factors; 2019-nCoV; mental health 
medRxiv preprint doi: https://doi.org/10.1101/2020.06.21.20137000; this version posted June 23, 2020. The copyright holder for this preprint (which was not certified by peer review) is the author/funder, who has granted medRxiv a license to display the preprint in perpetuity.

It is made available under a CC-BY-NC-ND 4.0 International license.

\section{Introduction}

In May 2020, the UN Secretary-General issued a message that the COVID-19 pandemic had resulted in massive mental suffering and called for actions. ${ }^{1}$ A number of studies have predicted the mental health of adults by means of demographic variables, ${ }^{2-5}$ but little research has predicted mental health based on adults' health status during the COVID-19 pandemic. This study is the first, to the best of our knowledge, to identify such predictors, specifically adults' health condition and availability of testing for COVID-19.

First, good health condition can lower individuals' chance of COVID-19 infection, and healthcare workers (e.g., general practitioners) may already have some knowledge of the health status of people under their care. Second, as individuals have heterogeneous access to COVID-19 testing due to limited testing capacity in many countries, individuals who have poorer access to COVID-19 testing may be more concerned or anxious about the COVID-19 pandemic. Test availability for COVID-19 is potentially a unique predictor of mental health during the COVID-19 pandemic.

\section{Methods}

The first case of COVID-19 in Malaysia was confirmed on February 4, 2020, and on March 18, 2020, Malaysia implemented a Movement Control Order (MCO) to ban citizens from non-essential travel and mass gatherings. The data for this study was collected by an online survey from May 2 to 8, 2020, six weeks after the implementation of the MCO. On May 8, 2020, there were a total of 6,535 confirmed cases of COVID-19 and 108 deaths. ${ }^{6}$ 
Even though we were not aiming for a fully representative sample, we applied two-stage stratified sampling in terms of ethnicity, gender, age, and geographical area ${ }^{7}$ to ensure coverage of all regions and ethnic groups in Malaysia. ${ }^{8}$ Participation in this survey was voluntary and participants could opt-out at any time. Moreover, participants were assured anonymity and confidentiality of their responses. The survey was granted ethical approval by Tsinghua University (20200322). The online survey was issued in Malay, Mandarin and English, the major languages used in Malaysia.

The participants reported their demographic characteristics, including gender, age, education level, number of children under 18 years old in the household, religion, and ethnic group. We assessed health condition using the global health measure SF- $1^{9}$ with a five-point scale from 1 to 5 (poor, fair, good, very good, excellent). To capture availability of testing for COVID-19 in Malaysia, we asked participants to rate the statement "I can get a test for COVID-19 rapidly if I need it" from 1 to 7 (strongly disagree, disagree, somewhat disagree, neither agree nor disagree, somewhat agree, agree, strongly agree). We used four dimensions for mental health: insomnia, anxiety, depression and distress.

Insomnia. Adults' insomnia was measured with the five-item Athens Insomnia Scale (AIS-5) ${ }^{10}$, including "I have trouble falling asleep" and "I feel tired and worn-out after my usual amount of sleep". The items were scored from 1 (to a very small extent) to 5 (to a very large extent). The Cronbach's alpha was $0 \cdot 82$.

Anxiety. Adults' anxiety was measured by the seven-item generalized anxiety 
disorder (GAD-7) ${ }^{11}$ scale. The seven items were scored from 0 (not at all) to 3 (nearly every day). The Cronbach's alpha was $0 \cdot 92$.

Depression. Adults' depression was measured with the nine-item Patient Health Questionnaire depression module (PHQ-9), ${ }^{12}$ with items scored from 0 (not at all) to 3 (nearly every day). The Cronbach's alpha was 0.90 .

Distress. Adults' psychological distress was measured with the six-item K6 screening scale, ${ }^{13}$ with items scored from 1 (all of the time) to 5 (none of the time). The Cronbach's alpha was 0.95.

We applied ordinary least squares (OLS) regression for the four dependent variables. Stata $16 \cdot 0$ was used to identify the predictors for insomnia, anxiety, depression and distress.

\section{Results}

\subsection{Descriptive findings}

Overall, 669 adults from all the states and federal territories of Malaysia participated in this survey. Table 1 shows the descriptive statistics of the sample. Participation by both genders was almost equal. The youngest participant was 21 years old and the oldest was 71 years old. Malaysia is a diverse country in terms of ethnicity and religion. Religion and ethnicity were reported in Table 1. Overall, our sample captured all the major ethnic and religious groups in Malaysia, but the sample is not taken as representative.

The average levels of mental health of adults in Malaysia were different from 
adults in other countries. The mean scores of insomnia (AIS-5), anxiety (GAD-7), depression (PHQ-9) and distress (K6) were 1.76 (SD = 0.84), 4.50 (SD = 4.90), 4.67 $(\mathrm{SD}=5 \cdot 12)$, and $5.95(\mathrm{SD}=6 \cdot 51)$, respectively. The mean scores of depression and anxiety in Malaysia were significantly lower than those in a sample of 300 adults collected on January 31 to February 7, 2020 in China $^{14}$ of $8 \cdot 3$ (difference $=-3 \cdot 63$, se $=$ $0 \cdot 39,95 \%$ CI: $-2 \cdot 95$ to $-4 \cdot 45, p<0 \cdot 001)$ and $7 \cdot 7$ (difference $=-3 \cdot 20$, se $=0 \cdot 37,95 \%$ CI: -2.47 to $-3.93, p<0.001)$, and also lower than scores in a sample of 1,009 adults on April 10-20, 2020 in Austria ${ }^{15}$ of $6 \cdot 20$ (difference $=-1 \cdot 53$, se $=0 \cdot 26,95 \%$ CI: $-0 \cdot 98$ to $-2 \cdot 02, p<0 \cdot 001$ ) and $5 \cdot 85$ (difference $=-1 \cdot 35$, se $=0 \cdot 26,95 \% \mathrm{CI}:-0.98$ to $-2 \cdot 02, p$ $<0.001$ ). The average degree of distress in a sample of 369 working adults (mean = 8.46) in China ${ }^{16}$ was significantly higher than in our sample (difference $=3 \cdot 36$, se $=$ $0 \cdot 32,95 \%$ CI: 3.98 to $2.74, p<0.001)$. The proportion of insomnia disorder in our sample $(38.9 \%, \mathrm{n}=669)$ was similar to that in a sample collected during April 10-13, 2020 in Greece $(37.6 \%, \mathrm{n}=2,427$, difference $=1.3 \%, p=0.540)$ during the COVID-19 pandemic. ${ }^{17}$ 
medRxiv preprint doi: https://doi.org/10.1101/2020.06.21.20137000; this version posted June 23, 2020. The copyright holder for this preprint (which was not certified by peer review) is the author/funder, who has granted medRxiv a license to display the preprint in perpetuity.

It is made available under a CC-BY-NC-ND 4.0 International license .

Table 1 Descriptive statistics of Malaysian participants

\begin{tabular}{|c|c|c|c|c|c|}
\hline Variables & $\begin{array}{c}\text { Description } \\
\mathrm{N}(\%)\end{array}$ & $\begin{array}{c}\text { Insomnia } \\
\text { Mean (SD) }\end{array}$ & $\begin{array}{c}\text { Anxiety } \\
\text { Mean (SD) }\end{array}$ & $\begin{array}{l}\text { Depression } \\
\text { Mean (SD) }\end{array}$ & $\begin{array}{c}\text { Distress } \\
\text { Mean (SD) }\end{array}$ \\
\hline Total & $669(100 \%)$ & $1.76(0.84)$ & $4 \cdot 36(4.89)$ & $4.49(5 \cdot 03)$ & $5 \cdot 10(5 \cdot 73)$ \\
\hline \multicolumn{6}{|l|}{ Gender } \\
\hline Male & $324(48 \cdot 43 \%)$ & $1.69(0.76)$ & $4 \cdot 04(4 \cdot 68)$ & $4 \cdot 02(4 \cdot 54)$ & $5 \cdot 25(6 \cdot 00)$ \\
\hline Female & $345(51.57 \%)$ & $1.84(0.91)$ & $4.66(5.06)$ & $4.93(5.43)$ & $4.96(5.48)$ \\
\hline \multicolumn{6}{|l|}{ Age (years old) } \\
\hline $20-29$ & $100(14.95 \%)$ & $1.89(0.79)$ & $5 \cdot 29(5 \cdot 00)$ & $5 \cdot 95(4 \cdot 72)$ & $5 \cdot 78(5 \cdot 83)$ \\
\hline $30-39$ & $197(29 \cdot 45 \%)$ & $1.99(0.91)$ & $5 \cdot 12(5 \cdot 10)$ & $5 \cdot 64(5 \cdot 67)$ & $5 \cdot 54(5 \cdot 89)$ \\
\hline $40-49$ & $192(28 \cdot 70 \%)$ & $1 \cdot 65(0.81)$ & $4 \cdot 37(4 \cdot 78)$ & $4 \cdot 16(4 \cdot 85)$ & $5 \cdot 02(5 \cdot 73)$ \\
\hline $50-59$ & $148(22 \cdot 12 \%)$ & $1 \cdot 58(0.76)$ & $3 \cdot 07(4 \cdot 32)$ & $3 \cdot 03(4 \cdot 19)$ & $4 \cdot 62(5 \cdot 77)$ \\
\hline $60-71$ & $32(4 \cdot 78 \%)$ & $1 \cdot 52(0 \cdot 74)$ & $2.69(4.80)$ & $1 \cdot 56(2 \cdot 84)$ & $2 \cdot 88(3 \cdot 27)$ \\
\hline \multicolumn{6}{|l|}{ Education level } \\
\hline Secondary school & $49(7 \cdot 32 \%)$ & $1 \cdot 71(0 \cdot 72)$ & $4.63(4 \cdot 72)$ & $4 \cdot 08(5 \cdot 24)$ & $6 \cdot 08(5 \cdot 77)$ \\
\hline College or university & $406(60 \cdot 69 \%)$ & $1.80(0 \cdot 86)$ & $4 \cdot 42(4 \cdot 81)$ & $4.69(4.97)$ & $5 \cdot 17(5 \cdot 71)$ \\
\hline Graduate school & $214(31.99 \%)$ & $1.70(0.83)$ & $4 \cdot 18(5 \cdot 08)$ & $4 \cdot 20(5 \cdot 11)$ & $4.73(5 \cdot 75)$ \\
\hline \multicolumn{6}{|l|}{ Number of children in household } \\
\hline $\cos$ & $322(48 \cdot 13 \%)$ & $1.78(0 \cdot 85)$ & $4 \cdot 30(4 \cdot 72)$ & $4 \cdot 77(5 \cdot 02)$ & $4 \cdot 79(5 \cdot 10)$ \\
\hline 1 & $114(17 \cdot 04 \%)$ & $1.69(0.82)$ & $4 \cdot 31(5 \cdot 18)$ & $4 \cdot 18(5 \cdot 02)$ & $5 \cdot 44(6 \cdot 63)$ \\
\hline 2 & $101(15 \cdot 10 \%)$ & $1.68(0.73)$ & $4 \cdot 21(4 \cdot 28)$ & $3 \cdot 89(4 \cdot 20)$ & $5 \cdot 61(5 \cdot 63)$ \\
\hline$\geq 3$ & $132(19 \cdot 73 \%)$ & $1.77(0.92)$ & $4 \cdot 48(5 \cdot 47)$ & $4 \cdot 25(5 \cdot 63)$ & $5 \cdot 36(6 \cdot 41)$ \\
\hline \multicolumn{6}{|l|}{ Religion } \\
\hline Islam & $352(52 \cdot 62 \%)$ & $1 \cdot 80(0 \cdot 88)$ & $4 \cdot 53(5 \cdot 06)$ & $4 \cdot 64(5 \cdot 24)$ & $5 \cdot 12(5 \cdot 80)$ \\
\hline Buddhism & $112(16 \cdot 74 \%)$ & $1.66(0.74)$ & $4 \cdot 38(4 \cdot 62)$ & $4 \cdot 39(4 \cdot 62)$ & $4 \cdot 97(5 \cdot 37)$ \\
\hline Hinduism & $24(3 \cdot 59 \%)$ & $1.93(0.83)$ & $5 \cdot 00(6 \cdot 47)$ & $4 \cdot 67(5 \cdot 47)$ & $6 \cdot 17(6 \cdot 03)$ \\
\hline Traditional Chinese religion & $26(3 \cdot 89 \%)$ & $1.63(0.78)$ & $3 \cdot 62(3 \cdot 61)$ & $4 \cdot 31(4 \cdot 92)$ & $4 \cdot 58(5 \cdot 93)$ \\
\hline Sikhism & $6(0 \cdot 90 \%)$ & $2.08(1.06)$ & $9 \cdot 83(7 \cdot 91)$ & $7 \cdot 17(5 \cdot 38)$ & $5 \cdot 83(4 \cdot 12)$ \\
\hline Christianity/Catholic & $124(18 \cdot 54 \%)$ & $1.73(0.82)$ & $3.44(3.76)$ & $3 \cdot 74(4 \cdot 42)$ & $4.99(5.98)$ \\
\hline Others & $3(0 \cdot 45 \%)$ & $1.33(0.58)$ & $0 \cdot 67(1 \cdot 15)$ & $0.67(1 \cdot 15)$ & $0 \cdot 67(1 \cdot 15)$ \\
\hline None & $22(3 \cdot 29 \%)$ & $1.91(0.94)$ & $6 \cdot 05(6 \cdot 21)$ & $6 \cdot 68(6 \cdot 19)$ & $5 \cdot 82(5 \cdot 42)$ \\
\hline \multicolumn{6}{|l|}{ Ethnic group } \\
\hline Malay & $328(49 \cdot 03 \%)$ & $1.78(0 \cdot 87)$ & $4 \cdot 41(5 \cdot 02)$ & $4 \cdot 59(5 \cdot 23)$ & $5 \cdot 07(5 \cdot 80)$ \\
\hline Chinese & $221(33.03 \%)$ & $1.65(0.76)$ & $3.91(4 \cdot 32)$ & $4 \cdot 18(4 \cdot 58)$ & $4 \cdot 77(5 \cdot 44)$ \\
\hline Indian & $36(5 \cdot 38 \%)$ & $1.94(0.87)$ & $5 \cdot 86(6 \cdot 70)$ & $5 \cdot 00(5 \cdot 17)$ & $7 \cdot 22(6 \cdot 61)$ \\
\hline Bumiputra of Sabah and Sarawak & $75(11 \cdot 21 \%)$ & $1.93(0.90)$ & $4 \cdot 84(4 \cdot 82)$ & $4 \cdot 56(5 \cdot 18)$ & $5.09(5 \cdot 47)$ \\
\hline Others & $9(1 \cdot 35 \%)$ & $1.78(0.74)$ & $3 \cdot 67(4 \cdot 50)$ & $5.67(6.98)$ & $5 \cdot 44(8 \cdot 03)$ \\
\hline \multicolumn{6}{|l|}{ COVID-19 test availability } \\
\hline Strongly disagree & $33(4 \cdot 93 \%)$ & $1.98(1.02)$ & $7 \cdot 97(7 \cdot 65)$ & $8 \cdot 24(7 \cdot 32)$ & $7 \cdot 55(6 \cdot 84)$ \\
\hline Disagree & $34(5 \cdot 08 \%)$ & $1.92(1.01)$ & $5 \cdot 26(5 \cdot 12)$ & $4 \cdot 79(5 \cdot 12)$ & $6 \cdot 06(6 \cdot 83)$ \\
\hline Somewhat disagree & $42(6 \cdot 28 \%)$ & $1.79(0 \cdot 69)$ & $3 \cdot 98(4 \cdot 26)$ & $4 \cdot 05(4 \cdot 25)$ & $6.98(7.43)$ \\
\hline
\end{tabular}


medRxiv preprint doi: https://doi.org/10.1101/2020.06.21.20137000; this version posted June 23, 2020. The copyright holder for this preprint (which was not certified by peer review) is the author/funder, who has granted medRxiv a license to display the preprint in perpetuity.

It is made available under a CC-BY-NC-ND 4.0 International license .

\begin{tabular}{rlcllll} 
Neither agree nor disagree & $150(22.42 \%)$ & $1.80(0.89)$ & $4.49(4.40)$ & $5.00(5.50)$ & $5.33(5.65)$ \\
Somewhat agree & $94(14.05 \%)$ & $1.73(0.71)$ & $3.77(4.04)$ & $4.02(3.79)$ & $4.85(5.69)$ \\
Agree & $227(33.93 \%)$ & $1.63(0.76)$ & $3.69(4.42)$ & $3.54(4.16)$ & $4.34(4.86)$ \\
\hline Health condition & Strongly agree & $89(13.30 \%)$ & $1.93(0.99)$ & $4.98(5.85)$ & $5.25(5.90)$ & $4.72(5.83)$ \\
\hline & & & & & \\
Poor & $7(1.05 \%)$ & $3.00(1.41)$ & $13.29(9.84)$ & $13.57(7.46)$ & $9.71(7.54)$ \\
Fair & $74(11.06 \%)$ & $2.15(1.00)$ & $7.41(5.78)$ & $7.09(5.80)$ & $6.85(5.52)$ \\
Good & $209(31.24 \%)$ & $1.80(0.82)$ & $4.46(4.63)$ & $4.63(5.09)$ & $4.89(5.15)$ \\
Very good & $250(37.37 \%)$ & $1.63(0.74)$ & $3.47(3.91)$ & $3.65(4.12)$ & $4.93(5.98)$ \\
Excellent & $129(19.28 \%)$ & $1.66(0.80)$ & $3.68(4.96)$ & $3.91(5.01)$ & $4.51(5.94)$ \\
\hline
\end{tabular}

\subsection{Predictors of insomnia, anxiety, depression, and distress}

Table 2 presents the results of the regression models. The quadratic terms of health condition (health condition - square in Table 2) were significant across the regressions for all four dimensions of mental health: insomnia $(\beta=0 \cdot 10,95 \%$ CI: $0 \cdot 03$ to $0 \cdot 17, p=0.003)$, anxiety $(\beta=0.79,95 \% \mathrm{CI}: 0.36$ to $1 \cdot 22, p<0.001)$, depression $(\beta$ $=0 \cdot 74,95 \%$ CI: 0.38 to $1 \cdot 11, p<0.001)$, and distress $(\beta=0.45,95 \%$ CI: 0.01 to $0 \cdot 88$, $p=0 \cdot 045)$, demonstrating curvilinear relationships between health condition and mental health dimensions. The margin analysis of the slope of insomnia by health condition was $-0.71(p<0.001)$ at "poor", $-0.51(p<0.001)$ at "fair", $-0.31(p<0.001)$ at "good", $-0 \cdot 10(p=0.017)$ at "very good", and $0 \cdot 10(p=0 \cdot 328)$ at "excellent" health condition, showing a horizontally reversed J-shaped curve across the scoring range of health condition. Similar curvilinear relationships were also observed from "poor" to "excellent" health condition for anxiety $(\mathrm{d}=-5 \cdot 34, p<0 \cdot 001 ; \mathrm{d}=-3 \cdot 76, p<0 \cdot 001$; $=-2 \cdot 18, p<0.001 ; \mathrm{d}=-0 \cdot 60, p=0 \cdot 019 ; \mathrm{d}=0.98, p=0 \cdot 114)$, depression $(\mathrm{d}=-5 \cdot 04, p$ $<0.001 ; \mathrm{d}=-3.55, p<0.001 ; \mathrm{d}=-2.06, p<0.001 ; \mathrm{d}=-0.57, p=0.024 ; \mathrm{d}=0.91, p=$ $0 \cdot 104)$ and distress $(\mathrm{d}=-3 \cdot 11, p=0.006 ; \mathrm{d}=-2 \cdot 21, p=0 \cdot 002 ; \mathrm{d}=-1 \cdot 32, p<0 \cdot 001 ; \mathrm{d}$ 
$=-0 \cdot 43, p=0 \cdot 188 ; \mathrm{d}=0 \cdot 46, p=0 \cdot 511)$.

The quadratic term of test availability (test availability - square in Table 2) was positively associated with anxiety $(\beta=0 \cdot 17,95 \% \mathrm{CI}: 0.03$ to $0 \cdot 31, p=0 \cdot 017)$ and depression $(\beta=0 \cdot 16,95 \%$ CI: 0.02 to $0.29, p=0.027)$. The margin analysis of the slope of anxiety by test availability was $-1.49(p<0.004)$ at "strongly disagree", $-1 \cdot 15$ $(p=0.002)$ at "disagree", $-0.81(p=0.001)$ at "somewhat disagree", $-0.48(p=0.001)$ at "neither disagree nor agree", $-0 \cdot 14(p=0 \cdot 311)$ at "somewhat agree", $0 \cdot 19(p=$ $0.423)$ at "agree", and $0.53(p=0.152)$ at "strongly agree", showing a horizontally reversed J-shaped curve across the scoring range of test availability. The margin analysis of the slope of depression by test availability demonstrated a similar pattern at the 7-point anchor from "strongly disagree" to "strongly agree" ( $\mathrm{d}=-1 \cdot 41, p=$ $0 \cdot 005 ; \mathrm{d}=-1 \cdot 10, p=0.003 ; \mathrm{d}=-0 \cdot 79, p=0.001 ; \mathrm{d}=-0 \cdot 48, p=0.001 ; \mathrm{d}=-0 \cdot 17, p=$ $0 \cdot 263 ; \mathrm{d}=0 \cdot 16, p=0 \cdot 562 ; \mathrm{d}=0 \cdot 46, p=0 \cdot 227)$.

In addition, age negatively predicted insomnia $(\beta=-0 \cdot 02,95 \% \mathrm{CI}:-0 \cdot 02$ to $-0 \cdot 01$, $p<0 \cdot 001)$, anxiety $(\beta=-0 \cdot 08,95 \%$ CI: $-0 \cdot 11$ to $-0 \cdot 05, p<0 \cdot 001)$, depression $(\beta=$ $-0 \cdot 11,95 \%$ CI: $-0 \cdot 14$ to $-0.08, p<0 \cdot 001)$ and distress $(\beta=-0 \cdot 06,95 \%$ CI: $-0 \cdot 10$ to $-0 \cdot 02, p=0 \cdot 005)$. Although we included religion and ethnicity in the regression model, insomnia, anxiety, depression and distress did not vary significantly by them $\cdot$ Significant results are shown in Figure 1. 
Table 2 Predictors of adults' insomnia, anxiety, depression and distress by regression analyses $(\mathrm{N}=669)$

\begin{tabular}{|c|c|c|c|c|c|c|c|c|}
\hline \multirow{2}{*}{ Variables } & \multicolumn{2}{|l|}{ Insomnia } & \multicolumn{2}{|l|}{ Anxiety } & \multicolumn{2}{|l|}{ Depression } & \multicolumn{2}{|l|}{ Distress } \\
\hline & $\beta(95 \% \mathrm{CI})$ & $p$-value & $\beta(95 \% \mathrm{CI})$ & $p$-value & $\beta(95 \% \mathrm{CI})$ & $p$-value & $\beta(95 \% \mathrm{CI})$ & $p$-value \\
\hline Health condition-square & $0 \cdot 10(0 \cdot 03$ to $0 \cdot 17)$ & $0 \cdot 003$ & $0.79(0.36$ to 1.22$)$ & $0 \cdot 000$ & $0.74(0.38$ to 1.11$)$ & $0 \cdot 000$ & $0.45(0.01$ to 0.88$)$ & $0 \cdot 045$ \\
\hline Health condition & $-0.91(-1.41$ to -0.42$)$ & $0 \cdot 000$ & $-6 \cdot 91(-10 \cdot 06$ to $-3 \cdot 77)$ & $0 \cdot 000$ & $-6 \cdot 53(-9 \cdot 18$ to $-3 \cdot 88)$ & $0 \cdot 000$ & $-4.00(-7 \cdot 08$ to -0.91$)$ & $0 \cdot 011$ \\
\hline Test availability-square & $0 \cdot 01(-0 \cdot 01$ to $0 \cdot 03)$ & $0 \cdot 404$ & $0.17(0.03$ to 0.31$)$ & $0 \cdot 017$ & $0 \cdot 16(0.02$ to 0.29$)$ & $0 \cdot 027$ & $0.02(-0.14$ to $0 \cdot 18)$ & $0 \cdot 790$ \\
\hline Test availability & $-0 \cdot 11(-0 \cdot 30$ to $0 \cdot 08)$ & 0.253 & $-1 \cdot 82(-3 \cdot 10$ to $-0 \cdot 55)$ & $0 \cdot 005$ & $-1.73(-2.99$ to -0.46$)$ & 0.007 & $-0.67(-2.08$ to $0 \cdot 75)$ & $0 \cdot 355$ \\
\hline Gender (Female) & $0 \cdot 08(-0.05$ to $0 \cdot 21)$ & $0 \cdot 214$ & $0.22(-0.48$ to 0.93$)$ & $0 \cdot 535$ & $0.49(-0.24$ to $1 \cdot 22)$ & $0 \cdot 190$ & $-0 \cdot 54(-1 \cdot 40$ to $0 \cdot 32)$ & $0 \cdot 217$ \\
\hline Age & $-0.02(-0.02$ to -0.01$)$ & $0 \cdot 000$ & $-0 \cdot 08(-0 \cdot 11$ to $-0 \cdot 05)$ & $0 \cdot 000$ & $-0 \cdot 11(-0 \cdot 14$ to $-0 \cdot 08)$ & $0 \cdot 000$ & $-0 \cdot 06(-0 \cdot 10$ to $-0 \cdot 02)$ & $0 \cdot 005$ \\
\hline Education level & $-0.05(0 \cdot 36$ to $-0 \cdot 15)$ & 0.056 & $-0 \cdot 25(-0 \cdot 86$ to $0 \cdot 36)$ & $0 \cdot 414$ & $-0 \cdot 10(-0.74$ to $0 \cdot 55)$ & $0 \cdot 770$ & $-0 \cdot 64(-1.40$ to $0 \cdot 12)$ & $0 \cdot 100$ \\
\hline Number of children & $0.02(-0.02$ to 0.07$)$ & $0 \cdot 331$ & $0 \cdot 16(-0.09$ to 0.41$)$ & $0 \cdot 209$ & $0 \cdot 02(-0 \cdot 27$ to $0 \cdot 30)$ & $0 \cdot 912$ & $0 \cdot 25(-0.07$ to 0.56$)$ & $0 \cdot 131$ \\
\hline \multicolumn{9}{|l|}{ Religion } \\
\hline Islam & \multicolumn{2}{|c|}{ Reference group } & \multicolumn{2}{|l|}{ Reference group } & \multicolumn{2}{|l|}{ Reference group } & \multicolumn{2}{|l|}{ Reference group } \\
\hline Buddhism & $-0 \cdot 12(-0 \cdot 54$ to $0 \cdot 31)$ & 0.593 & $-0 \cdot 02(-2 \cdot 39$ to $2 \cdot 35)$ & 0.986 & $0.61(-1.75$ to 2.96$)$ & $0 \cdot 613$ & $0.15(-2.66$ to $2 \cdot 97)$ & 0.916 \\
\hline Hinduism & $0.08(-0.62$ to 0.79$)$ & $0 \cdot 814$ & $-0 \cdot 02(-4 \cdot 10$ to $4 \cdot 07)$ & 0.994 & $1 \cdot 13(-2 \cdot 77$ to $5 \cdot 04)$ & $0 \cdot 569$ & $-3 \cdot 34(-10 \cdot 00$ to $3 \cdot 32)$ & $0 \cdot 325$ \\
\hline Traditional Chinese religion & $-0 \cdot 15(-0 \cdot 64$ to $0 \cdot 35)$ & $0 \cdot 561$ & $-0 \cdot 80(-3 \cdot 29$ to $1 \cdot 69)$ & $0 \cdot 529$ & $0 \cdot 71(-2 \cdot 09$ to $3 \cdot 51)$ & $0 \cdot 618$ & $-0 \cdot 37(-3 \cdot 89$ to $3 \cdot 16)$ & $0 \cdot 837$ \\
\hline Sikhism & $0 \cdot 11(-0 \cdot 8$ to $1 \cdot 03)$ & $0 \cdot 807$ & $3 \cdot 78(-2 \cdot 57$ to $10 \cdot 13)$ & $0 \cdot 243$ & $3 \cdot 31(-1 \cdot 23$ to $7 \cdot 84)$ & $0 \cdot 153$ & $-4 \cdot 90(-11 \cdot 86$ to $2 \cdot 07)$ & $0 \cdot 168$ \\
\hline Christianity/Catholic & $-0 \cdot 12(-0.51$ to $0 \cdot 27)$ & 0.546 & $-1 \cdot 56(-3 \cdot 71$ to $0 \cdot 58)$ & $0 \cdot 154$ & $-0 \cdot 22(-2.39$ to 1.95$)$ & $0 \cdot 840$ & $-0 \cdot 16(-2 \cdot 65$ to $2 \cdot 33)$ & 0.900 \\
\hline Others & $-0 \cdot 77(-1 \cdot 89$ to $0 \cdot 34)$ & $0 \cdot 175$ & $-6 \cdot 10(-11 \cdot 52$ to $-0 \cdot 69)$ & $0 \cdot 027$ & $-5 \cdot 64(-10 \cdot 54$ to $-0 \cdot 74)$ & $0 \cdot 024$ & $-6 \cdot 22(-10 \cdot 94$ to $-1 \cdot 50)$ & $0 \cdot 010$ \\
\hline None & $0 \cdot 12(-0 \cdot 40$ to $0 \cdot 64)$ & $0 \cdot 642$ & $1.40(-1.90$ to 4.69$)$ & $0 \cdot 406$ & $2 \cdot 70(-0 \cdot 46$ to $5 \cdot 85)$ & $0 \cdot 094$ & $0 \cdot 42(-2 \cdot 98$ to $3 \cdot 83)$ & $0 \cdot 807$ \\
\hline \multicolumn{9}{|l|}{ Ethnic group } \\
\hline Malay & \multicolumn{2}{|c|}{ Reference group } & \multicolumn{2}{|l|}{ Reference group } & \multicolumn{2}{|l|}{ Reference group } & \multicolumn{2}{|l|}{ Reference group } \\
\hline Chinese & $-0.03(-0.45$ to $0 \cdot 39)$ & 0.873 & $-0 \cdot 03(-2 \cdot 30$ to $2 \cdot 23)$ & 0.977 & $-1 \cdot 08(-3 \cdot 33$ to $1 \cdot 16)$ & $0 \cdot 343$ & $-0 \cdot 31(-2.98$ to $2 \cdot 37)$ & $0 \cdot 823$ \\
\hline Indian & $0 \cdot 17(-0.49$ to 0.82$)$ & 0.622 & $1 \cdot 24(-2 \cdot 30$ to $4 \cdot 78)$ & $0 \cdot 491$ & $-0 \cdot 78(-4 \cdot 17$ to $2 \cdot 61)$ & $0 \cdot 651$ & $5 \cdot 30(-1 \cdot 23$ to $11 \cdot 84)$ & $0 \cdot 111$ \\
\hline Bumiputra of Sabah and Sarawak & $0 \cdot 19(-0 \cdot 19$ to $0 \cdot 58)$ & $0 \cdot 329$ & $1 \cdot 25(-0 \cdot 91$ to $3 \cdot 41)$ & $0 \cdot 256$ & $-0 \cdot 38(-2 \cdot 52$ to $1 \cdot 77)$ & $0 \cdot 731$ & $0 \cdot 07(-2 \cdot 22$ to $2 \cdot 36)$ & $0 \cdot 951$ \\
\hline Others & $0 \cdot 24(-0 \cdot 32$ to $0 \cdot 80)$ & $0 \cdot 405$ & $0 \cdot 80(-2.59$ to 4.20$)$ & $0 \cdot 642$ & $1.59(-2.34$ to 5.52$)$ & $0 \cdot 427$ & $2 \cdot 16(-4 \cdot 09$ to $8 \cdot 42)$ & 0.497 \\
\hline
\end{tabular}


medRxiv preprint doi: https://doi.org/10.1101/2020.06.21.20137000; this version posted June 23, 2020. The copyright holder for this preprint (which was not certified by peer review) is the author/funder, who has granted medRxiv a license to display the preprint in perpetuity.

\section{It is made available under a CC-BY-NC-ND 4.0 International license.}
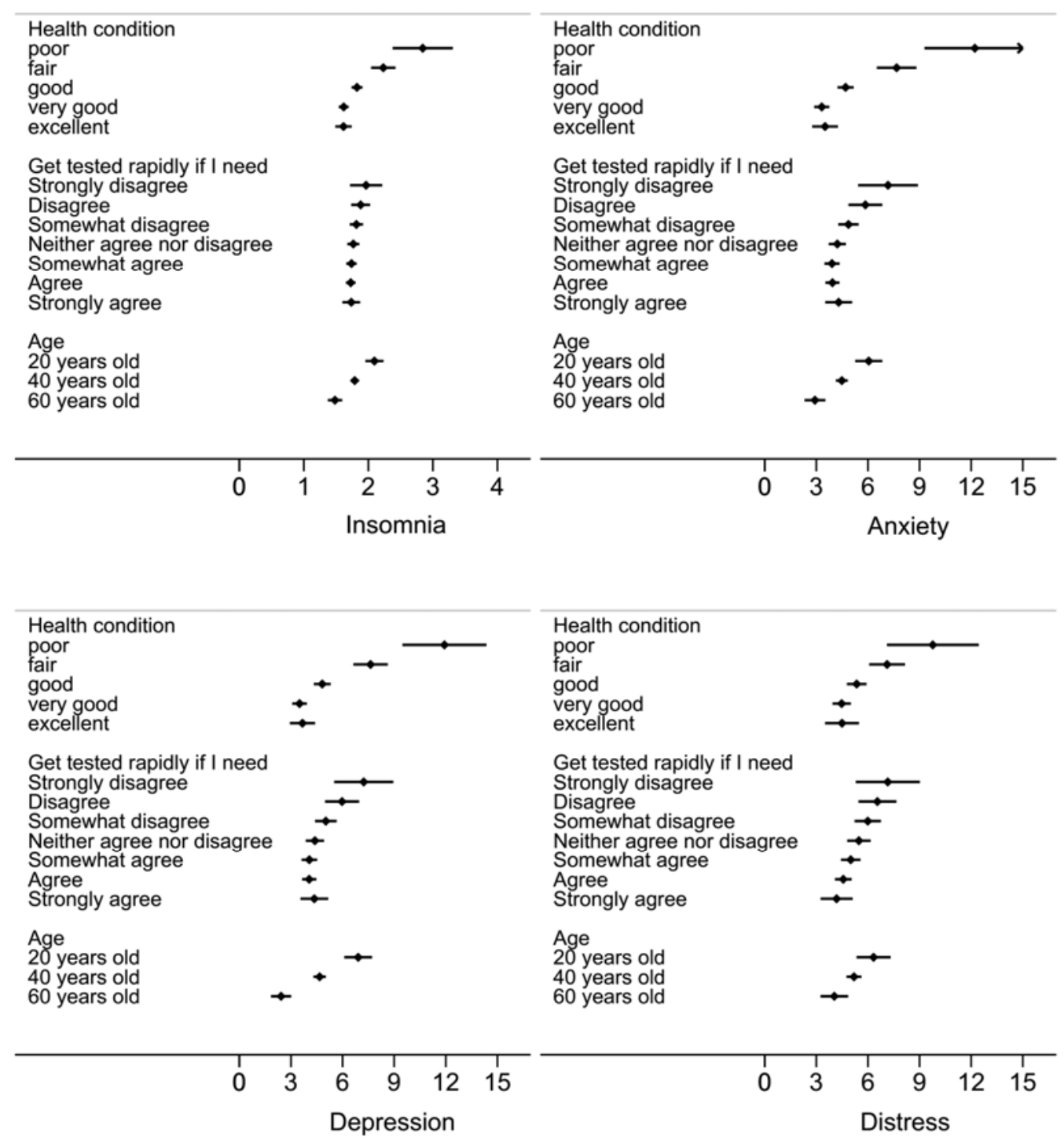

Figure 1 Predicted value and $95 \%$ confidence intervals (CIs) of insomnia, anxiety, depression and distress by health condition, COVID-19 test availability and age. 
medRxiv preprint doi: https://doi.org/10.1101/2020.06.21.20137000; this version posted June 23, 2020. The copyright holder for this preprint (which was not certified by peer review) is the author/funder, who has granted medRxiv a license to display the preprint in perpetuity.

It is made available under a CC-BY-NC-ND 4.0 International license .

\section{Discussion}

This study identifies several predictors of insomnia, anxiety, depression, and distress among adults in Malaysia during the COVID-19 pandemic. Consistent with past studies, ${ }^{5,18}$ age was found to be a predictor of mental health problems for the general population in Malaysia. This is also consistent with studies of healthcare workers, where older healthcare workers were less likely to have mental health problems. ${ }^{19,20}$ However, other predictors found in the literature, such as education ${ }^{16}$ and gender, ${ }^{17}$ failed to predict mental health among adults in Malaysia, similar to a study in the UK. ${ }^{5}$ Our results suggest that future research should identify the effect of education and gender across more countries and future meta-analysis should identify contingent factors. Religion and ethnic group did not predict Malaysian adults' mental health, consistent with another Malaysian study ${ }^{21}$ which found that ethnicity is not correlated with mental health disorder. In line with previous research, our findings highlight the need to identify specific predictors of mental health under various contexts of the COVID-19 pandemic. ${ }^{19}$

More importantly, this study uncovers two unique risk factors for mental health. The first risk factor is existing health condition, which had significant curvilinear relationships with insomnia, anxiety, depression and distress. The results indicated that adults with worse reported health condition had worse mental health, especially for those at the lower end of the health spectrum. In other words, individuals' existing health condition is a useful screener of insomnia, anxiety, depression and distress for less healthy adults.

The second risk factor is test availability for COVID-19 having curvilinear 
medRxiv preprint doi: https://doi.org/10.1101/2020.06.21.20137000; this version posted June 23, 2020. The copyright holder for this preprint (which was not certified by peer review) is the author/funder, who has granted medRxiv a license to display the preprint in perpetuity.

It is made available under a CC-BY-NC-ND 4.0 International license .

relationships with anxiety and depression. Test unavailability predicted worse anxiety and depression, especially for people who disagreed that they could get tested for COVID-19 when needed. There was also no significant difference in mental health among people who "somewhat agreed", "agreed" and "strongly agreed" that they could get a COVID-19 test. Test availability could be a predictor of mental health, especially for adults who reported they lack access to COVID-19 tests.

Our findings suggest that healthcare service providers could use adults' general health condition and COVID-19 test availability to identify mentally vulnerable adults. The curvilinear relationships highlight the need to pay more attention to adults with poor health condition and adults who lack access to a COVID-19 test. Healthcare service providers such as hospitals may be able to use the health records of their patients and COVID-19 testing coverage to help identify those who need more mental health assistance.

\subsection{Limitations and future work}

Firstly, we used a two-stage stratified sampling method to aim for a broader coverage of Malaysian adults, but our study did not aim for a representative sample of adults in Malaysia during the COVID-19 pandemic. Secondly, we used SF-1, a brief one-item measure of general health condition, and future research may use the lengthier form of SF-12 or SF-36. Thirdly, instead of general health condition, future research may explore specific medical issues, such as heart disease, diabetes, or cancer, as predictors of mental health. Fourthly, we measured adults' perceived test availability for COVID-19 because we were interested in their mental health and 
future research may use alternative indicators of COVID-19 test availability.

\subsection{Conclusion}

This study identified two unique predictors of health condition and test availability for COVID-19 for Malaysian adults' mental health, operationalized as insomnia, anxiety, depression and distress. Unlike the demographic predictors identified in prior research, these two risk factors suggest new risk factors to predict mental health. Moreover, these predictors carried quadratic associations with various mental health dimensions, implying a need to focus on curvilinear predictors of mental health.

\section{Contribution Statement}

H. D.: Visualization, Writing - Original Draft, Writing - Review \& Editing

S. X. Z.: Conceptualization, Investigation, Methodology, Formal analysis, Writing Original, Writing - Review \& Editing

K. H. L.: Investigation (data collection), Writing - Review \& Editing

R. S.: Investigation (data collection)

J. L.: Resources, Funding acquisition

\section{DECLARATION OF COMPETING INTEREST}

The authors declare that each author has no conflicts of interest with respect to the research, authorship, and/or publication of this article. 
medRxiv preprint doi: https://doi.org/10.1101/2020.06.21.20137000; this version posted June 23, 2020. The copyright holder for this preprint (which was not certified by peer review) is the author/funder, who has granted medRxiv a license to display the preprint in perpetuity.

It is made available under a CC-BY-NC-ND 4.0 International license.

\section{ACKNOWLEDGEMENT}

We acknowledge the support of Tsinghua University-INDITEX Sustainable

Development Fund (Project No. TISD201904). 
medRxiv preprint doi: https://doi.org/10.1101/2020.06.21.20137000; this version posted June 23, 2020. The copyright holder for this preprint (which was not certified by peer review) is the author/funder, who has granted medRxiv a license to display the preprint in perpetuity.

It is made available under a CC-BY-NC-ND 4.0 International license .

\section{References}

1 Gomes R. Covid-19: UN urges actions on mental health. 2020; published online May https://www.vaticannews.va/en/world/news/2020-05/united-nations-guterres-kestel -mental-health-action-covid19.html (accessed June 12, 2020).

2 Kang L, Ma S, Chen M, et al. Impact on mental health and perceptions of psychological care among medical and nursing staff in Wuhan during the 2019 novel coronavirus disease outbreak: A cross-sectional study. Brain Behav Immun 2020; 87: 11-7.

3 Lai J, Ma S, Wang Y, et al. Factors associated with mental health outcomes among health care workers exposed to coronavirus disease 2019. JAMA Netw Open 2020; 3: e203976-e203976.

4 Steel Z, Silove D, Phan T, Bauman A. Long-term effect of psychological trauma on the mental health of Vietnamese refugees resettled in Australia: a population-based study. The Lancet 2002; 360: 1056-62.

5 Shevlin M, Nolan E, Owczarek M, et al. COVID $\square 19 \square$ related anxiety predicts somatic symptoms in the UK population. Br J Health Psychol 2020; : 10.1111/bjhp.12430.

6 COVID-19 Coronavirus Pandemic. Worldometer. https://www.worldometers.info/coronavirus/country/malaysia/ (accessed June 20, 2020).

7 Goodman LA. Statistical methods for the mover-stayer model. J Am Stat Assoc 1961; 56: 841-68.

8 Demographics of Malaysia. $\quad$ Wikipedia. https://en.wikipedia.org/wiki/Demographics_of_Malaysia (accessed June 21, 2020).

9 Levy DE, Chang Y, Regan S, Tindle HA, Singer DE, Rigotti NA. Improvements in health-related quality of life among smokers who quit after hospitalization. Prev Med 2018; 110: 38-46.

10Soldatos CR, Dikeos DG, Paparrigopoulos TJ. Athens Insomnia Scale: validation of an instrument based on ICD-10 criteria. J Psychosom Res 2000; 48: 555-560.

11 Spitzer RL, Kroenke K, Williams JBW, Löwe B. A Brief Measure for Assessing Generalized Anxiety Disorder: The GAD-7. Arch Intern Med 2006; 166: 1092-7.

12 Kroenke K, Spitzer RL, Williams JBW. The PHQ-9 validity of a brief depression severity measure. J Gen Intern Med 2001; 16: 606-13. 
medRxiv preprint doi: https://doi.org/10.1101/2020.06.21.20137000; this version posted June 23, 2020. The copyright holder for this preprint (which was not certified by peer review) is the author/funder, who has granted medRxiv a license to display the preprint in perpetuity.

It is made available under a CC-BY-NC-ND 4.0 International license .

13 Kessler RC, Green JG, Gruber MJ, et al. Screening for serious mental illness in the general population with the K6 screening scale: results from the WHO World Mental Health (WMH) survey initiative. Int J Methods Psychiatr Res 2010; 19: $4-22$.

14 Yao H. The more exposure to media information about COVID-19, the more distressed you will feel. Brain Behav Immun 2020; : S0889159120308783.

15Pieh C, Budimir S, Probst T. Mental health during COVID-19 lockdown: A comparison of Austria and the UK (May 4, 2020). ; : Available at SSRN: https://ssrn.com/abstract=3592372 or http://dx.doi.org/10.2139/ssm.3592372.

16Zhang SX, Wang Y, Rauch A, Wei F. Unprecedented disruption of lives and work: Health, distress and life satisfaction of working adults in China one month into the COVID-19 outbreak. Psychiatry Res 2020; 288: 112958.

17 Voitsidis P, Gliatas I, Bairachtari V, et al. Insomnia during the COVID-19 pandemic in a Greek population. Psychiatry Res 2020; 289: 113076.

18Zhang C, Yang L, Liu S, et al. Survey of insomnia and related social psychological factors among medical staff involved in the 2019 novel coronavirus disease outbreak. Front Psychiatry 2020; 11: 306.

19Zhang SX, Liu J, Jahanshahi AA, et al. At the height of the storm: Healthcare staff's health conditions and job satisfaction and their associated predictors during the epidemic peak of COVID-19. Brain Behav Immun 2020; : S0889159120307832.

20Zhang SX, Sun S, Jahanshahi AA, et al. Developing and testing a measure of COVID-19 Organizational Support of Healthcare Workers - Results from Peru, Ecuador, and Bolivia. Psychiatry Res 2020; : 113174.

21 Raaj S, Tharmaselan M, Navanathan S. An overview of the mental health burden in Malaysia. Jr Dr Netw 2020; : 28-30. 